\title{
Written Literature in an African Language: An Examination of Interrogative Sentences in Fágúnwà's Novels
}

\author{
Tèmítọ́pẹ́ Olúmúyìwáa and Aládésanmí Ọmọ́bọ́lá Agnes*b \\ ${ }^{a}$ Department of Linguistics and Languages \\ Adékúnlé Ajásin University, Àkùngbá-Àkókó, Nigeria \\ ${ }^{b}$ Department of Linguistics and Nigerian Languages \\ Ekiti State University, Ado-Ekiti, Nigeria
}

Received 01.03.16, received in revised form 05.05.16, accepted 27.06.16

Fágúnwà is no doubt a great Yorùbá novelist, who has impressively extended the frontiers of the Yorùbá literary heritage due to his skill as a story-teller and his linguistic competence in the use of Yorùbá language. Many incidents in his novels are designed to teach morals. In his effort to teach these morals and expand the reader's knowledge and understanding about the messages contained in the novels, Fágúnwà shows great skills in the use of interrogative sentences. It is against this backdrop that this study, therefore, examines the nature and use of interrogative sentences in his five novels. The study shows that Fágúnwà uses a total of 678 interrogative sentences in the novels. The study posits that Fágúnwà uses the interrogative sentences for various reasons which include: introduction of moral and social vices he condemns; creating humor; showing emotions in some characters and making some of his narrative techniques effective.

Keywords: Fágúnwà, Interrogative sentences, Novels, Yorùbá language.

DOI: 10.17516/1997-1370-2016-9-12-3025-3036.

Research area: philology.

\section{Introduction}

AfricanLanguages are numerous, genetically related and diverse in nature. Grimes (1996) puts the number of African languages at 2,035. This figure represents nearly one-third of the world languages (Heine \& Nurse 2000:1). The African languages are classified into the following: language phyla: Afroasiatic, Nilo-Saharan, Niger-Congo and Khoisan. This study focuses on Yorùbá, one of the languages of Niger-Congo
Language phylum. Grimes (1996) estimates the languages in this phylum to be 1,436 , making it the largest language phylum in the world. Yorùbá is one of the three recognized Nigerian major languages. Yorùbá people in Nigeria are estimated to be about 43 million. They occupy a large area in the South-West geopolitical zone of Nigeria extending through Lagos, Ògùn, Ọyọ́, Òndó, Ọsun, Èkìtì, Kwara, Kogi and Edo States. Yorubá is also spoken in the republics of Benin,

(C) Siberian Federal University. All rights reserved

* Corresponding author E-mail address: oluolumuyiwa@gmail.com, bolaaladesanmi@gmail.com 
Togo, Brazil, Cuba, Sierra-Leone and Trinidad and Tobago. Yorùbá language was reduced to writing by Bowdich (a British diplomat in the Gold Coast) in 1817. The standardization of the language began mainly through the efforts of the Church Missionary Society (CMS) in 1875. However, the publication of the compilation: the serial of İtàn Èmi Șẹgilọlá Ẹlẹyinjú-ẹgẹ Elẹgbẹ̀rún ọkọ láiyé (The life Story of Șẹgilọlá Elẹéyinjú-ẹgẹ́, the wife to a thousand husbands) in July, 1930 by I. B. Thomas, marked the birth of Yorùbá novel writing, Ògúnșínà (1992:15). Eight years after, Daniel Oròwọlé Fágúnwà, another novelist, came to the scene.

Daniel Oròwọlé Fágúnwà (D.O. Fágúnwà), was born in 1903 in Òkè-Igbó, Ondó State, South West Nigeria. He was the son of Joshua Akíntúndé and Racheal Ọșúnyọmí Fágúnwà. D.O. Fágúnwà's parents were adherents of Yorùbá traditional religion before they were converted to Christianity. The Christian doctrines probably influenced Oròwọlé Fágúnwà to change 'Oròwọlé' (Orò cults enters home) to 'Olọ́runfẹ́mi' (God loves me). D.O. Fágúnwà started schooling in 1916 at St. Luke's Primary School, Òkè-Igbó. He graduated in 1924 and later became a teacher at the same school in 1925. He entered St. Andrew's Teachers College Òyộ in 1926. On completion of his studies in 1929, he began his teaching career at St. Andrew's Practicing School between 1930 and 1939.

It was during this period of his life, in 1935, when Fágúnwà's first novel Ògbójú ode Ninú Igbó Olódùmarè (Ògbójú) (Forest of A Thousand Demons) was written. The book was presented for a competition organized by Miss Plummer in 1936. The Church Missionary Society bought the manuscript and published it in 1938.

D.O. Fágúnwà was posted to St. Patrick's Primary School, Ộọ̀, Ondó State in 1940. He moved to Church Missionary Society (CMS) Grammar School Lagos in 1943. In 1944,
Fágúnwà moved to Girls' College of Benin City and later to Igbóbì College of Lagos in 1945. He was in Britain in 1947 and later returned to Nigeria in 1948 after his studies there. D.O. Fágúnwà ended his teaching career at Government Teacher Training Centre Ìbàdàn in 1950. He later worked as an Education Officer at the Publication Unit of the Ministry of Education in the old Western Region of Nigeria till 1959. He was conferred with the honour M.B.E in 1959. Later that year, he became Nigeria Representative of Heinemann Education Books. Other novels written by Fágúnwà are: Igbó Olódùmarè (Forest of God) (1949), İrèké Oníbùdó (1949), İrinkèrindò Nínú Igbó Elégbèje (Adventures to the Mount of Thought) (1954), and Ádìtú Olódùmarè (The Mystery Plans of God) (1961). These novels underwent several impressions after they were first published. Fágúnwà also wrote some other books, which include İrànșẹ Eni Olọrun Tì Léyin (unpublished manuscript 1939), İrìn-àjò Edá apá kíní àti apá kejì (1959) and Táiwò ati Kẹ́hìndé (1964). He jointly wrote the books İtan Olóyin (1959) with L.J. Lewis, and Òjó Asọtàn with G.L. Laṣebikan, which were published posthumously in 1964 . Fágúnwà died on December 7, 1963¹.

D.O. Fágúnwà is reported to have had the strongest impact on the development of Yorùbá novel writing. Ògúnșínà (1992:78) describes Fágúnwà's place in the history of Yorùbá novel writing as significant in the sense that he impressively extended the frontiers of Yorùbá literary heritage in a fresh dimension, thus bringing an instant and yet unsurpassed continuity into Yorùbá novel writing. Fágúnwà's greatness as a Yorùbá novelist has been linked to his skill as a story-teller and his use of Yorùbá language. Critics of Fágúnwà’s works unanimously speak of his superlative use of the language. Fágúnwà's language gymnastics include the use of short sentence sequences, 
repetition of words, proverbial expressions, hyperbole and declamatory utterances, vivid and fanciful comparisons, ebullient rhetorical effects and humour. In describing Fágúnwà's linguistic competence and his artistic ability to achieve lucidity without boredom, Bámgbóșé (1974) describes him as a master of Yoruba language, who creatively exploits the genius of the language by twisting it to express his feelings and those of his characters. In the same vein, Beier (1967:189) points out that the true Yorùbá flavour of Fágúnwà's works lies not in the material he used, but in the language of his narration.

The major scholarly work on the language use in novels by Fágúnwà was written by Bámgbóșé (1974: 108-132). The work posits that Fágúnwà's language is characterized by the rhetoric which shows itself in the love for words, hyperbolic expressions and declamatory speech. The work also examines the use of the following stylistic features: simile and metaphor, idiophones, proverbs, short sentence sequences, expressive imagery, repetition, humour and negative personification. Another aspect of language use in Fágúnwà's novels which has not been examined yet is his use of interrogative sentences which is the main concern of this study. Therefore, the main thrust of the study is to examine the use and functions of the interrogative sentences in five novels by Fágúnwà. We chose to investigate the use and functions of interrogative sentences in the five novels because previously they have been ignored.

Each of the Fágúnwà's novels is a novel of actions (Ògúnșínà 1992:77). And many incidents in the novels are designed to teach morals. As Bámgbóșé (1975:943) correctly pointed out, each novel is a didactic document embodying an account of the trials and tribulations of a fellow human from whom we are supposed to learn a lesson. As a trained teacher, Fágúnwà knew the importance of questioning as an instructional tool in the dialogue of teaching and learning. In his effort to teach and expand the reader's knowledge and understanding of the lessons/messages conveyed by his novels, he shows great skills in the use of interrogative sentences. This is evident in the number of interrogative sentences used in the novels. In all, Fágúnwà used 678 interrogative sentences. In Ògbójú Odẹ Nínú Igbó Irúnmolẹ (Forest of A Thousand Demons) (1938), (Ògbójú) he used 119 interrogative sentences; 96 in Igbó Olódùmarè(Forest of God) (1949), (Igbó); 99 in İrèké Oníbùdó (1949), (İrèké); 95 in İrìnkèrindò Ninú Igbó Elégbèje (Adventures to the Mount of Thought)(1954), (İrinkèríndo); 269 in Àdìtú Olódùmarè (The Mystery Plans of God) (1961), (Àdiitú). The breakdown of the interrogative sentences used in each chapter of the novels is shown in the Tables below:

This can be represented graphically as shown in Fig. 1 below.

The tables in Fig. 1 below show that there are no interrogative sentences in chapters three and five of Irinkèrindò. This, we believe, is due to the fact that the two chapters are a mere narration of events. The tables also show that Fágúnwà used more interrogative sentences in Àdiìtú than in other novels. The reason for this cannot be farfetched. Firstly, the first person narrative technique is abandoned in favour of narrative by an omniscient narrator. Secondly, the novel centres on the mysteries of God. It is therefore not surprising that it generates more questions than others. Finally, the numerous interrogative sentences in Fágúnwà's novels as shown in the Tables below arouse our curiosity, thus, we decide to investigate its nature and use in the novels.

\section{Interrogative Sentences}

Several linguists have looked at interrogative sentences in natural languages. Among them, there are Bámgbóṣé (1967:43), Ògúnbọ̀wálé (1970:102-106), Awóbùlúyì (1978:123), Radford 
Table 1. Interrogative sentence in Fagunwa novels

\begin{tabular}{|c|c|c|c|c|c|}
\hline Chapter & Ogboju & Igbo & Ireke & Irinkerindo & Adiitu \\
\hline 1 & 6 & 1 & 4 & 14 & 3 \\
\hline 2 & 11 & 32 & 31 & 10 & 15 \\
\hline 3 & 7 & 11 & 8 & & 17 \\
\hline 4 & 3 & 7 & 4 & 23 & 7 \\
\hline 5 & 33 & 8 & 23 & & 13 \\
\hline 6 & 27 & 29 & 17 & 2 & 61 \\
\hline 7 & 24 & 2 & 12 & 4 & 41 \\
\hline 8 & 8 & 6 & & 17 & 78 \\
\hline 9 & & & & 17 & 18 \\
\hline 10 & & & & 1 & 16 \\
\hline 11 & & & & 7 & \\
\hline TOTAL & 119 & 96 & 99 & 95 & 269 \\
\hline
\end{tabular}

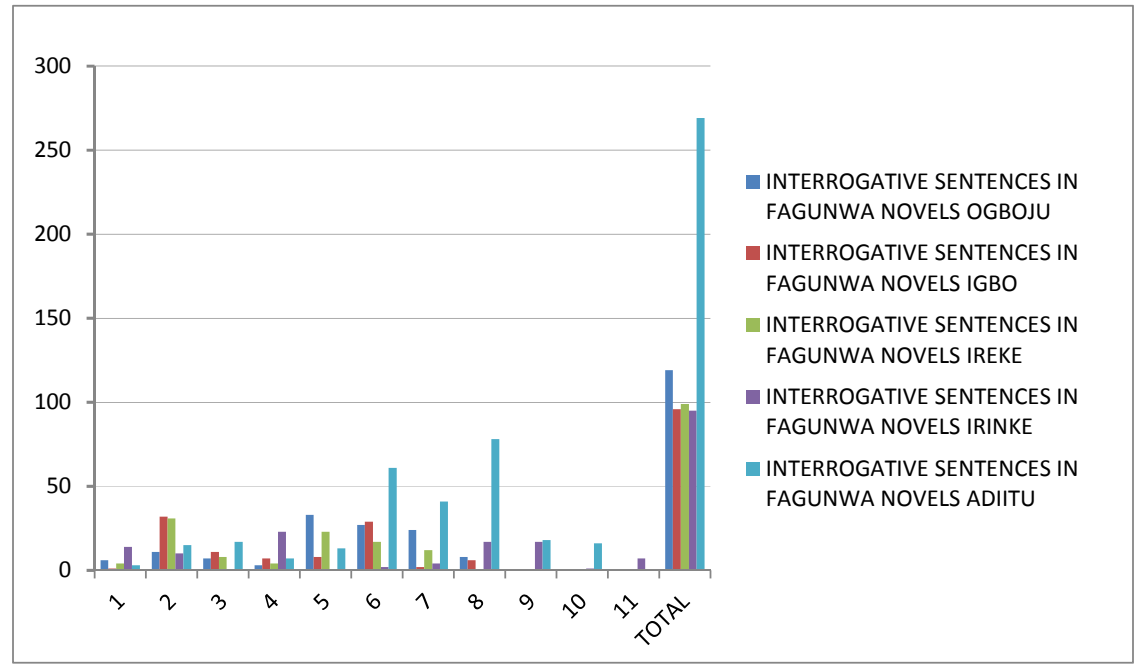

Fig. 1

(1988), Abọ́dẹrìn (1995), Crystal (2003) and Haegeman (2006). Bámgbóșé (1967:43) opines that any clause which has a question item in it is an interrogative clause in Yorùbá. The question items may be clause introducers, initial items in a $n i$ - clause, verbs or adverbs. Awóbùlúyì (1978:123) believes interrogative sentences are sentences employed as questions. They are of two basic kinds in Yorùbá: interrogative sentences that contain question words and those without question words which usually have a special rising intonation pattern.

Sentences with an interrogating structure mostly convey that there is a certain amount of information which the speaker does not have and which he is trying to make the interlocutor supply, (Haegeman 2006:21). This implies that questions are statements which seek information and expecting a reply. Crystal (2003:218) says that questions fall into three main types depending on 
the kind of reply one expects, and on how such questions are constructed. These types are: YesNo questions (polar questions), Wh-questions (content word questions) and alternative questions. Yes-No questions allow an affirmative or negative response. Wh-questions begin with question words and allow a reply from a wide range of possibilities, while alternative questions require a reply which relates to the options provided by the sentence.

The terms "question" and "interrogative" are often interchanging (Matthews 2007:200). However, a distinction can sometimes be made. Thus, "can't he shut up?" has an interrogative structure, and its function is not a question, but a request or a command. Questions are used by people in all walks of life to learn about their world and find information to guide their lives. Questions also confront people with a challenge. There are two domains of questions: cognitive and affective. Cognitive questions concern intellectual understanding. Affective questions concern emotions, attitudes and values. Sometimes, it is difficult to distinguish affective questions from cognitive questions. This is partly so because each affective question has a cognitive part to it. As Kissock and Iyortsuun (1995:79) correctly pointed out: "cognitive questions focus attention on the idea or information being studied. Affective questions focus attention on the individual and his/her opinion, feeling, or belief about something".

Formation of Interrogative Sentences in Yorùbá Language

The interrogative pattern of declarative sentences in English language is formed by changing the position of the auxiliary verb with respect to that of the subject (subject- auxiliary inversion-moving the auxiliary leftward across the subject). For example:

1. Declarative: "The murderer has broken the window"
Interrogative: "Has the murderer broken the window?"

However, in Yorùbá language, there are two types of interrogative constructions: those that contain question words and those without question words. Interrogative sentences without question words are pronounced specially with the voice lighter and higher for such constructions than their declarative versions. Interrogative constructions that contain question words are of two basic kinds. These are yes/no (polar) and content word (wh-) interrogative constructions. Polar questions in Yorùbá are derived by adjoining either of two question head elements ǹjẹ or șé to the beginning of declarative sentences as exemplified below:

\begin{tabular}{|c|c|c|}
\hline Declarative: & $\begin{array}{l}\text { Olúwátișé } \\
\text { jẹun. }\end{array}$ & $\begin{array}{l}\text { "Olúwátișé } \\
\text { ate". }\end{array}$ \\
\hline \multirow[t]{2}{*}{ Interrogative: } & $\begin{array}{l}\text { Șé Olúwátișé } \\
\text { jẹun? }\end{array}$ & $\begin{array}{l}\text { "Did } \\
\text { Olúwátișé } \\
\text { eat?" }\end{array}$ \\
\hline & $\begin{array}{l}\text { Ǹjẹ Olúwátiṣé } \\
\text { jẹun? }\end{array}$ & $\begin{array}{l}\text { "Did } \\
\text { Olúwátișé } \\
\text { eat?" }\end{array}$ \\
\hline
\end{tabular}

Unlike ǹjệșé, which occur at the beginning of the sentence, bí and ndan are polar elements that occur at the end of Yorùbá polar question sentence, as in:
3.
a. Dayọ̀ wá bí?
"Did Dayọ̀ come?"
b. Wọ́n sọ̀rọ̀ ndan?
"Are they talking?"

The process of forming content word questions in Yorùbá involves movement. Content word questions in Yorùbá are nominal expressions which are often moved to the beginning of the sentence where they are immediately followed by the focus marker ni, (Ìlọ̀rí 2010:256). Yorùbá content word questions are ta 'who', èwo/wo 'which', ibo 'where', báwo 'which', èló 'how much', mélòó 'how many', nítorí kí... 'why'. This is illustrated by the following examples: 
4. (a) Délé rí Ta Ta ni Delé "Who did (ni) ní ọjà $\rightarrow$ rí... ní ojà? Délé see at the market?"

(b) Moyè rí Olú Ibo ni Moyè "Where did ní ibo $\rightarrow \quad$ ti rí Olú? Moyè see

(c) O gbọ́ kí (ni) Kí ni o "What did $\rightarrow \quad$ gbọ́...? $\quad$ you hear?"

(d) Wọ́n ta Mélòó ni "How much mélòó $\rightarrow \quad$ wọ́n tà...? did they

(e) O máa dé Nígbà wo ni "When are nígbà wo $\rightarrow$ o máa dé...? you coming?"

(f) E fẹ́ èwo Èwo ni ẹ fẹ́ "Which níbẹ̀ $\rightarrow$ níbẹ̀...? one do you want?"

(g) İyẹn jẹ èló $\rightarrow$ Èló ni ìyẹn "How much jẹ́...? is that?"

These content word questions demand phrasal or clausal answers. There are other types of content word question constructions which do not involve wh-items. Examples of such question expressions are:
5. a. Ó ti jẹ́?
"How is it?"
b. Așọ mi dà?
"Where is my cloth?"
c. İyá rẹ ńkọ́?
"Where is your mother?"
d. Ó tí ì lọ ná?
"Has he gone yet?"

The discussions in the preceding paragraphs have focused attention on interrogative sentences and their formation in Yorùbá language with the hope that this background will help us in our examination of interrogative sentences in Fágúnwà's novels.

\section{The Nature of Interrogative Sentences in Fágúnwà's Novels}

The general nature of interrogative sentences used in Fágúnwá's novels is similar to the ones used in conversation in contemporary Yorùbá. In the novels, Fágúnwà used interrogative sentences majorly when there is interactivity between the speaker and the interlocutor. Some of the interrogative sentences used in the novels are directed at the interlocutor. In the novels, the following interrogative sentences are found: (a) Wh-questions; (b) alternative questions; (c) polar questions and (d) interrogative sentences without questions words.

Fágúnwà used Wh-question type more than other types in the novels. The linguistic patterns of Wh-questions in Fágúnwà's novels are simple, short and sometimes identical. As shown in (6) below.

6. i. Tani baba wọn? Tani baba enia?.. Tani baba agbọ̀nrin? İrinkèridò p. 113.

Who is their father? Who is the father of man...Who is the father of antelope?"

ii. Tani ọ? *Kini ọ? (sic)... kil'ò nwa? Kil'o nfẹ? Nibo l'o ti mbọ? Igbó p. 14.

"Who are you? What are you? What are you looking for? What do you want? Where are you coming from?

iii Tani ẹnyin wọ̀nyi? Nibo ni ẹ ti wá? Nibo ni ẹ si nlọ? Ògbójú p. 61.

"Who are these people? Where did you come from? Where are you going?"

iv Tani ẹnyin wọnyi? Kilẹ gbẹ kẹ̀lé? Nibo lẹ ti nbọ? İrèké p. 110.

Who are these people? What did you depend on? Where are you coming from?

The question items ta, níbo, kí occur in the beginning of the sentence as in (6) above. The question items in (6) above conform to their linguistic usage in Yorùbá language, except that kí 'what' as asterisked in (6ii) was inappropriately used. Kí is used to ask about non-human in Yorùbá language. Likewise, ńkọ "where" is incorrectly used in some cases. Its incorrect use in Igbó p. 3, 15, 35, 95 and Irinkèrindò $\mathrm{p} 43$ is noticed in this type of construction:

7. *nitorí kini nkọ? "What do you base it on?"

The question element ńkọ cannot co-occur with the question element kí in Yorùbá. The 
correct version of interrogative sentences in (7) above should be:

8. Nítorí kí ni? "What do you base it on?"

The incorrect use of ńkó "where" in the instances mentioned above may be pardonable because the question element is correctly used elsewhere in the novels. Its correct use is noticed in the following examples.

\begin{tabular}{|c|c|c|c|}
\hline i. & $\begin{array}{l}\text { Ojọ́ mesan } \\
\text { oni nkọ? }\end{array}$ & $\begin{array}{l}\text { İrìnkèridò } \\
\text { p. } 75\end{array}$ & $\begin{array}{l}\text { "What of in } \\
\text { nine days' } \\
\text { time?" }\end{array}$ \\
\hline ii. & $\begin{array}{l}\text { Aja ilé rẹ } \\
\text { nkọ? }\end{array}$ & Addìtú p. 7 & $\begin{array}{l}\text { "How is the } \\
\text { dog in your } \\
\text { house?" }\end{array}$ \\
\hline iii. & Iya rẹ nkọ? & Ògbójú p. 82 & $\begin{array}{l}\text { "Where } \\
\text { is your } \\
\text { mother?" }\end{array}$ \\
\hline
\end{tabular}

Similarly, bệe is another word used incorrectly in interrogative sentences in Ògbójú p. 44 and Igbó pp. 33 and 44 as shown in the following examples:

10. i. 'Njẹ ìwọ ni Anjọnnu-ibẹru ti iṣe onibode Igbo Olodumare bẹ̃ p33.

"Are you Ànjọnnu-ibẹru, the gate-keeper of Igbó Olodumare?"

ii. Njẹ iwọ ni ọkunrin na ti o pa Anjọnnuibẹru bẹ̃ ? p. 44

"Are you the man that killed Ànjọ̣nnúìbẹ̀rù?"

iii. Akara-ogun, njẹ iwo mọ̀ pe awọn ara ilu yi ngbero ati pa oba bệp. 44.

"Àkàrà-oògùn, do you know that the people of this town wanted to kill the king?"

The three interrogative sentences in (10) are grammatically correct without the word bẹ. The word bẹ performs no function in the interrogative sentences. However, our observation in examples (7) and (10) above must not give the impression that language use in Fágúnwà's novels is bad. We want to believe that the observations in (7) and (10) could be traceable to Fágúnwà's idiolects at the time of writing the novels.
The use of alternative questions in Fágúnwà's novels is usually done as in formal Yoruba discourse. Consider the following:

11. i... A ó șe tiwa tàbí a kò ni ṣe tiwa? Ògbójú p. 57

"Are we going to fulfill our course or not"

ii ... nwọn bara mu tabi nwọn kò ba ra mu? Àdiìtú p. 93

“... Are they compatible or not?"

iii. "Alafia ni ẹnyin $n$ ba bọ tàbí kùmọ̀?" İrìnkèridò p. 57

"Are you coming in peace or not?"

The speakers of the utterances in (11) above intended to request the interlocutor to choose from the options in the interrogative sentences.

At times, Fágúnwà creatively used interrogative sentences in his novels by combining two or more as a sentence. Consider (12) below.

12. i. “... Àláfíà kọ ni ile wa bi, ara kole bi, șe kò si nkan?” Igbó p. 24

"Is it well with your home? How is your body, is all well?"

ii. "Nibo ni iwọ ti wa nibo ni iwọ si nlọ?" Ògbójú p. 42

"Where are you coming from, where are you going?"

The use of interrogative sentences this way shows the skill in Fágunwà's use of Yorùbá language. Also, the use of polar questions in the dialogue between all the Lámọ́rín and Alágá in Àdìtú pp114-115 is picturesque. Fágúnwà innovatively presents the polar questions in the dialogue between Alága 'Chairman' and Lámorin without using the polar question elements: ǹjẹ́, ṣé, and bí. Consider 13 below.

$\begin{array}{ll}\text { 13. Alága: Iwọ ni } & \text { "You are the first } \\ \text { Lamọrin kini? } & \text { Lamọrin?" } \\ \text { Lámọrin: Bẹ̃ ni } & \text { "Yes" } \\ \text { Alága: A bi ọ ni ọjọ } 2 & \text { "You are born on } 2 \\ \text { oṣu June 1922. } & \text { June 1922." } \\ \text { Lámọrín: Bẹ̃ ni } & \text { "Yes" }\end{array}$

13. Alága: Iwọ ni "You are the first Lamọrin kini? Lamọrin?’

Alága: A bi ọ ni ọjọ 2

Lámọrín: Bẹ̃ni

"Yes" 


$\begin{array}{ll}\text { Alága: O ti kọ } & \text { "You have fully } \\ \text { Olodumare silẹ } & \text { rejected God" } \\ \text { patapata } & \\ \text { Lámọrin: Bẹ̃ ni } & \text { "Yes" }\end{array}$

Fágúnwà uses this innovation to show the craftiness of Alága (chairman) in entrapping his victims. The interrogative adverb ndan, the use of which was in vogue during Fágúnwà era, was used twenty-four times in the novels. The interrogative adverb performs no function in the interrogative sentences where it occurs in the novels. This interrogative adverb has gone out of use in contemporary Yorùbá language, probably because it is old-fashioned.

\section{The Function of Interrogative Sentences in Fágúnwà's Novels}

Learning to communicate in a language involves more than acquiring its pronunciation and grammar. If we are to use language in a realistic way, we need to learn the uses to which utterances are conventionally put and how these uses are signalled. People use language principally as a tool to do things: ask questions, request a favour, report events, converse, teach, greet and so on. In a terminology introduced by Austin (1975: 23) such functions of language are called speech acts. Each speech act has several principal components, two of which are directly relevant in this section: the utterance itself (locution) and the intention of the speaker in making it (illocution). Hence, in this section, we shall examine the communication intents of Fágúnwà as regard his use of interrogative sentences in his novels.

One of the important features of speech acts is interactivity. Interactivity is a communicating function which involves the speaker in a coordinated activity with other language users (Saeed 2009:231). While a speech act like asking a question does not need any explicit responses to make them a question, they nonetheless set up the expectation for an interactive response. In all the novels, Fágúnwà uses interrogative sentences mainly for interactive responses in order to meet communicative demands of all the characters. This is why almost all the interrogative sentences used in the novels emanated from interactive response between one character and another. However, there are other communication intents for the use of interrogative sentences in the novels.

Fágúnwà has been described as a writer who shows an incredible feeling for words and their effects. In his use of language, he is a clever innovator who brings new life into stereotyped expressions and succeeds in holding the readers' attention by his verbal dexterity and manipulation of sentence patterns (Bámgbóṣé 1975:953). In his novels, Fágúnwà uses some interrogative sentences to introduce a number of moral and social vices he condemns. For instance, in Ògbójú (p. 53), he uses a sequence of twenty-two interrogative sentences to teach and comment on some of the things that can cause rancour amidst the couple. In a similar vein, he uses interrogative sentences to introduce and explain the causes of untimely death among the children in İrèké (pp. 57-58). Aside this, some of the moral stories incorporated into his narration are introduced by interrogative sentence(s). The Sage, who tells these stories in novels, always begins some of the stories by asking a cognitive question. This is evident in the story of Kìnùun and Kọ̀lộ kọ̀lọ (the lion and the fox) in Ògbójú (p. 82), and also in the story of Kòtẹ́milọ́rùn in Àdìtú (p. 112125), where Fágúnwà uses seventy interrogative sentences for illustration. The dialogue between Alága and the first five Lámọrín is used to show covetousness and discontent in man.

Bámgbóṣé (1974:127) describes Fágúnwà as a humorous writer without telling us how he does it. One of the ways Fágúnwà creates humour in the novels is by using interrogative sentences in the dialogue between some characters. Let's 
take, for example, the dialogue between Ẹkùn and Ológbò-İjàkadì and between Ẹkùn and his wife. The humorous dialogue shows the stupidity of Ekùn and the mocking tone of Ekùn's wife in İrèké (pp. 21-44). Likewise, the dialogue between Omùgọdiméjì and his visitors in İrìkèrindò (pp. 42-46) is also humorous. Òmùgọ̀diméjì uses eight interrogative sentences to eulogize himself and his palace despite his unusual and repugnant behaviour. In the same vein, Fágúnwà uses the interrogative sentences in the dialogue between Alága and the last two new initiates to create humour in Àdìtú (pp. 124-125).

One of the narrative techniques in Fágúnwà's novels is direct address. Bámgbóṣé (1975:946947) has correctly pointed out that the adoption of this technique arises from the writer's conception of his role as a story-teller and his acute awareness that he is addressing an audience. However, one opines that Fágúnwà uses some of the interrogative sentences in his novels to make this technique effective by creating direct, intimate and audience participation. For instance, the interrogative sentences he uses in Àdìtú (p. 1) is directed at the audience and this, we believe, allows for the audience's participation in the narration. Also in Àdìtú (p. 3), Fágúnwà employs some interrogative sentences to show intimacy between him (the fictional author) and the narrator. Interrogative sentence is also employed to introduce the first dream of the fictional author in İrèké (p. 7). Another narrative technique in which Fágúnwà uses interrogative sentences is what Bámgbósé calls "cross reference". In order to recapitulate the past events, Fágúnwà employs eight interrogative sentences in Ògbójú (p. 71) and five interrogative sentences in İrèké (pp. 117118).

Fágúnwà's language is remarkable for its music and rhythm and poetic quality of many of the passages in his novels (Bámgbóșé 1975:950). However, we note that this observation is evident in his use of interrogative sentences in İrìnkèrindò (p. 113), where he uses the interrogative sentences to capture the rhythm and atmosphere of drum language when he says:

"Tani baba wọn? Tani baba enia? Tani baba wọn? Tani baba àgbọ̀nrín?

Tani baba wọn? Tani baba ìmàdò? Tani baba wọn?"

"Who is their father? Who is the father of man? Who is their father? Who is the father of antelope? Who is their father? Who is the father of the wart-hog? Who is their father?"

Also, Fágúnwà employs some affective questions in order to show emotions in some of his characters. This is shown, firstly, in the interrogative sentences used in the love letters in İrèké (pp. 79, 84, 90, 91); İrìnèrindò (pp. 73, 74, 75, 77, 80, 81) and Adìitú (pp. 7, 59, 63, 64, 79, 80, 81, 87). Secondly, when İrìkèrindò and Àdìtú Olódùmarè lost their loved ones in İrìnkèrindò (p. 8) and Àdìtú (p. 37) and thirdly, when the king wanted to send Àkàràoògùn to Òkè Láńgbòdó in Ògbójú (p. 49). Finally, Fágúnwà shows how Yorùbá can use interrogative sentences to resolve conflicts in the society. This is evident in the story of certain man and a leopard in Ògbójú (pp. 91-93).

\section{Conclusion}

This study has discussed interrogative sentences in Fágúnwà novels. In the course of this, we were able to describe the nature of interrogative sentences he used. The study shows that Fágúnwà uses wh-question type more than other question types. The study also notes that some question items are used in the novels wrongly. The study concludes by examining some of the communicative intents in the use of the interrogative sentences in the novels. The study posits that some of the interrogative sentences used are not used to seek information, but rather, they are used to supply 
information in the narration. Aside this, some of the interrogative sentences are employed to make some of the narrative techniques effective, to create humour and to show emotions of some characters.

\section{End Note}

This is abridging version of the history of D.O. Fágúnwà. His history has been fairly documented in detail in Olúbùńmọ̀ (1964), Bámgbóṣé (1974) and Ògúnșínà (1992).

\section{References}

Abọ́dẹrìn, O.A. (1995) 'Ọ̀nà İṣẹ̀dá Gbólóhùn Ìbéèrè Nínú Èdè Yorùbá' M.A Thesis, Ọbáfẹ́mi Awólọ́wọ̀ University, Ilé-Ifẹé.

Adétùgbọ́, A. (1967) 'The Yorùbá Language in Western Nigeria: Its Major Dialects Areas' Ph.D Dissertation, Columbia University, New York.

Adétugbọ́, A. (1973) 'The Yorùbá language in Yorùbá History in Sources of Yorùbá History. Biobaku (ed.) Ibadan: University Press Limited.

Akínkúgbé, O.O. (1976) 'An Internal Classification of the Yoruboid Group: Yorùbá, Isẹkiri, Igala' Journal of West African Languages, xi:1-18.

Awóbùlúyì, O. (1978) Essentials of Yorùbá Grammar. Ibadan: Oxford University Press.

Awóbùlúyì, O. (1998) ‘Àwọn Ẹka-èdè Yorùbá’ paper read at YSAN Conference, Pastoral Institute, Bodija, İbàdan.

Austin, J.L. (1975) How to Do Things with Words. Oxford: Clarendon Press.

Bámgbóșé A. (1967) A short Yorùbá Grammar, Ìbàdàn: Heinemann Educational Books (Nigeria) Ltd.

Bámgbóșé, A. (1974) The Novels of D.O. Fágúnwà, Benin-City: Ethiope Publishing Corporation.

Bámgbóșé, A. (1975) 'Fágúnwà and The Yorùbá Folktale Tradition’ in Abímbộlá W. (ed.) Yorùbá Oral Tradition: Poetry in Music Dance and Drama,935-955. Department of African Languages and Literatures, University of Ifẹ̀.

Beier, U. (1967) 'D.O Fágúnwà: A Yorùbá Novelist' in Ulli Beier(ed.) Introduction to African Literature. London: Longmans, 188-195.

Crystal, D. (2003) The Cambridge Encyclopedia of the English Language. Cambridge: Cambridge University Press.

Fágúnwà, D.O. (1938) Ògbójú Odẹ Ninú Igbó Irúnmolẹ Nelson Publishers Limited.

Fágúnwà, D.O. (1949) Igbó Olódùmarè Nelson Publishers Limited.

Fágúnwà, D.O. (1949) İrèké Oníbùdó Lagos: Thomas Nelson (Nigeria) Ltd.

Fágúnwà, D.O. (1954) İrìnkèrindò Nínú Igbó Elégbèje Lagos: Thomas Nelson (Nigeria) Ltd.

Fágúnwà, D.O. (1961) Àdìtú Olódùmarè Lagos: Thomas Nelson (Nigeria) Ltd.

Fágúnwà, D.O. (ed.) (1963) İtan Olóyin London: Oxford University Press.

Fágúnwà, D.O and Láṣebìkan, L. (1964) Òjó Asọ̀tàn London: Heinmann Educational Books Ltd.

Grimes, B.F. (Ed.) (1996) Ethnologue: Languages of the world Dallas Summer Institute of Linguistics and the University of Texas at Arlington.

Haegeman, L. (2006) Thinking Syntactically: A Guide to Argumentation and Analysis. Blackwell Publishing. 
Heine B \& Nurse D. (Eds.) (2000) African Languages: An Introduction Cambrigde University Press.

Igue, J. (1973) 'The Yorùbá-speaking peoples of Dahomey and Togo' in Yorùbá : Journal of Yorùbá Association of Nigeria Vol. 1:1, 1973. Print.

Ilori, J.F. (2010) 'Nominal Constructions in Igálà and Yorùbá” Ph.D Thesis, Department of Linguistics and Languages, Adekunle Ajasin University, Akungba-Akoko.

Kissock, C and Iyortsuun, P.A. (1982) Guide to Questioning: Classroom Procedures for teachers. London: The Macmillan Press Ltd.

Matthews, P.H. (2007) Oxford Concise Dictionary of Linguistics, New York: Oxford University Press.

Ògúnbọ̀wálé, P.O. (1970) The Essentials of the Yorùbá. U.K. Hodder and Stoughton.

Ògúnșínà, B. (1992) The Development of the Yorùbá Novel 1930-1975 Ìbàdàn: Gospel Faith Mission Press.

Olúbùnmọ̀, A. (1964) 'Àwọn òǹọ̣wé Yorùbá òde òní: Daniel Ọlọ́runfẹ́mi Fágúnwà (apá kini) 1903-1963' Olókun No. 4, 15-23.

Oyèláràn, O. (1976) 'Linguistics Speculations on Yorùbá History', Department of African Languages and Literatures, University of Ifẹe Seminar Series No 1 part II. 624-651.

Radford, A. (1988) Transformational Grammar. A first Course. U.K: Cambridge University Press.

Saeed, J.I. (2009) Semantics Blackwell Publishing Ltd.

Thomas, I.B. (1930) İtàn İgbésí Aiyé Èmi Ṣegilọlá Lagos C.M.S. Nig. Bookshops.

Williamson, K and Blench, R. (2000) 'Niger-Congo' in Heine B. and Nurse, D. (Eds.) African Languages: An Introduction. Cambridge: Cambridge University Press.

\title{
Письменная литература на африканских языках: исследование вопросительных предложений \\ в романах Даниела Фагунвы
}

\author{
Темитопе Олумуйива, Аладесанми Омобола Агнес \\ а Факультет языков и лингвистики \\ Университет имени Адекунле Аджасина, Акунгба-Акоко \\ Нигерия \\ ${ }^{6}$ Факультет лингвистики и нигерийких языков \\ Университет штата Экити, Адо-Экити \\ Нигерия
}

Без сомнения, Фагунва - это великий романист йоруба, сумевший значительно расширить литературное наследние йоруба благодаря его искусству рассказчика, а также за счет его высочайтего мастерства в использовании языка йоруба. Многие из его романов несут в себе поучительный смысл. Стремясь донести до читателя тот или иной урок, а также расширить познания читателя, позволить ему лучше понять сообщение, которое несет в 
себе роман, Фагунва блестяме использует вопросительные предложения. Таким образом, данное исследование направлено на изучение характера использования вопросительных предложений в пяти романах автора. Исследование показало, что всего в романах встречается 678 вопросительных предложений. Авторы приходят к выводу, что Фагунва использует вопросительные предложения по разным причинам, среди которых: изобличение моральных и социальных пороков; создание юмористического эффекта; выражение эмоций персонажей и повышение эффективности повествовательных приемов.

Ключевые слова: Фагунва, вопросительные предложения, романы, язык йорубы.

Научная специальность: 10.00.00 - филологические науки. 